\title{
Performance of common bean genotypes in the region of Campo Novo do Parecís - MT
}

\author{
Rosivaldo HIOLANDA ${ }^{1}$, Anderson Morais KIMECZ ${ }^{1}$, Leonardo Cunha MELO², \\ Flávio Carlos DALCHIAVON ${ }^{1 *}$
}

\author{
${ }^{1}$ Instituto Federal de Educação, Ciência e Tecnologia de Mato Grosso, Campo Novo do Parecis, MT, Brazil. \\ ${ }^{2}$ Embrapa Arroz e Feijão, Empresa Brasileira de Pesquisa Agropecuária, Santo Antônio de Goiás, GO, Brazil. \\ *E-mail: flavio.dalchiavon@enp.ifmt.edu.br
}

Submitted in November /2017; Accepted in August /2018.

\begin{abstract}
The objective of this work was to evaluate the agronomic performance of common bean genotypes, black commercial group, grown in the region of Campo Novo do Parecis, state of Mato Grosso. The experiment was set and conducted from February to May 2016/2017 in the experimental area of the production sector of the Instituto Federal de Educação, Ciência e Tecnologia de Mato Grosso - IFMT Campus Campo Novo

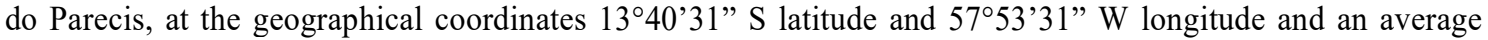
elevation of $574 \mathrm{~m}$. The experimental design was complete randomized, with 12 treatments (nine lines and three standards) and three replications. Plant height, stem diameter, days for initial flowering, days for physiological maturation, number of pods per plant, number of grains per pod, number of grains per plant, mass of one hundred grains and grain yield were evaluated in this study. Data were submitted to analysis of variance and to the ScottKnott mean test, both at 5\% probability. Black common bean is a crop that grows well on the Parecis's region, allowing mechanized harvesting for good resistance to lodging. Grain yield may be satisfactory as long as there is no water stress in the reproductive phase. Among the evaluated genotypes, the BRS FP403, CNFP 15697 and CNFP 15684 showed good productive performance. Investment is necessary to achieve a good yield because the crop is demanding in water.
\end{abstract}

Keywords: cultivation value and use, genetic plant breeding, Phaseolus vulgaris.

\section{Desempenho de genótipos de feijão preto na região de Campo Novo do Parecis - MT}

RESUMO: O objetivo do trabalho foi avaliar o desempenho agronômico de genótipos de feijão comum, grupo comercial preto, cultivados na região de Campo Novo do Parecis - MT.O ensaio foi instalado e conduzido, entre os meses de fevereiro e maio de 2016 e 2017, na área experimental do setor de produção do Instituto Federal de Educação, Ciência e Tecnologia de Mato Grosso - IFMT Campus Campo Novo do Parecis, cujas coordenadas geográficas são latitude S $13^{\circ} 40^{\prime} 31^{\prime \prime}$ longitude $\mathrm{O} 57^{\circ} 53^{\prime} 31^{\prime \prime}$ e altitude média de $574 \mathrm{~m}$. O delineamento experimental foi em blocos casualizados, com 12 tratamentos (nove linhagens e três padrões) e três repetições. Foram avaliadas as características agronômicas altura da planta, diâmetro do caule, dias para o florescimento inicial, dias para a maturação fisiológica, número de vagens por planta, número de grãos por vagem, número de grãos por planta, massa de cem grãos e produtividade de grãos. Os dados submetidos à análise de variância e ao teste de média Scott-Knott, ambos a 5\% de probabilidade. O feijão comum preto é uma cultura que se desenvolve bem no chapadão do Parecis, permitindo a colheita mecanizada pela boa resistência ao acamamento. A produtividade de grãos pode ser satisfatória, desde que não ocorra estresse hídrico na fase reprodutiva. Entre os genótipos pesquisados, o BRS FP403, CNFP 15697 e CNFP 15684 se destacaram no desempenho produtivo. Para obter um bom rendimento é necessário investimento, pois a cultura é exigente em água.

Palavras-chave: melhoramento genético vegetal, Phaseolus vulgaris, valor de cultivo e uso.

\section{INTRODUCTION}

In Brazil, common bean (Phaseolus vulgaris L.) is an important agricultural product of major socioeconomic importance, especially because it is one of the primary sources of protein and energy in the diet of most of the population (TSUTSUMI et al., 2015).

Black beans is the second most cultivated type of grain in the country, largely consumed in the States in the southern region, in Rio de Janeiro, in southeastern Minas Gerais and in the south of Espírito Santo. In addition, it can be grown in three harvests: rainy season (October to January), dry season: (February to May) and winter (June to September), according to the agroclimatic zoning of each region (MELO et al., 2007).
Brazil is the world's largest producer of common beans, with an average yield of $922 \mathrm{~kg} \mathrm{ha}^{-1}$, while the world's production is around $776 \mathrm{~kg} \mathrm{ha}^{-1}$; however, bean cultivation per area still shows a small yield in the Brazil, according to data from the Food and Agriculture Organization of the United Nations - FAO (FAO, 2010). The probable causes are associated to the occurrence of pests and pathogens, low fertility, presence of toxic elements in the soil, which results in a reduction in the growth of the root system (SOUZA et al., 2006).

In order to achieve a successful crop, it is important to gather all the conditions that favor the expression of a full productive potential of a plant. The choice of a proper area and selection of the correct cultivar, quality of the seeds and the 
sowing operation, especially with regard to the season, the depth at which the seeds are placed, the spacing between rows and the number of seeds per meter are very important factors and should be considered.

The adaptability of common bean genotypes, specific for each region, brings a number of benefits to the farmer, since not all cultivars respond well in all regions because of the local environmental conditions, such as temperature, humidity, and photoperiod, which interfere in the development of the crop, significantly reducing its yield. Thus, studies have been carried out with the objective of assisting in the recommendation of cultivars with high productive capacity, stability and adaptability for different regions of the country (MELO et al., 2007; PEREIRA et al., 2009).

Thus, the objective of this work was to obtain technical information regarding the agronomic performance of the common bean, black commercial group, in order to give technical support to the farmers for choosing the best fit genotype to the region.

\section{MATERIAL AND METHODS}

The study was repeated in two years, from February to May in 2016/2017, in the experimental area of the Instituto Federal de Educação, Ciência e Tecnologia de Mato Grosso IFMT (Federal Institute of Education, Science and Technology of Mato Grosso) Campo Novo do Parecis campus - MT, at the geographic coordinates of $13^{\circ} 40^{\prime} 31^{\prime \prime} \mathrm{S}$ latitude and 57 53'31" $\mathrm{W}$ longitude at an average elevation of $574 \mathrm{~m}$. The soil in the experimental area, according to the Brazilian Soil Classification System recommended by the Brazilian Agricultural Research Corporation - EMBRAPA (EMBRAPA, 2013) and referred to in Dalchiavon et al. (2015), is a typical dystroferric Red Latosol, with smooth undulating relief and good drainage.

The climate in the region is Aw type, according to the classification of Köppen, tropical climate with dry winter and rainy summer. The dry season in the region is well defined and occurs from May to September and the rainy season is from October to April (DALLACORT et al., 2011). The averages occurred during the experimental period were: $24.1 ; 31.6$ and $19.5^{\circ} \mathrm{C}(2016)$ and $24.0 ; 31.1$ and $19.9^{\circ} \mathrm{C}$ (2017) for average, maximum and minimum temperatures, respectively, as well as cumulative precipitations of 447.6 (2016) and $603.4 \mathrm{~mm}$ for 2017 (Figures 1a,b), which perfectly meets the water requirement of the crop, which is between 300 to $600 \mathrm{~mm}$ for the state of Mato Grosso, regularly distributed over its growth cycle (SANTOS et al., 2013).

The experimental design was a complete randomized block (CRB), with 12 treatments (nine lines and three black bean genotypes, standard) with three replications, totaling 36 plots. Each replicate had four rows spaced by $0.45 \mathrm{~m}$, with 5 $\mathrm{m}$ in length, totaling $9.0 \mathrm{~m}^{2}$.

The area used for bean sowing was at rest in the 2015/16 crop and cultivated with pearl millet in the $2016 / 17$ crop as a cover crop, which was dried 20 days before bean sowing. In the desiccation, glyphosate $792.5 \mathrm{~g} \mathrm{~kg}^{-1}$ (2.5 L c.p. ha- $\left.{ }^{-1}\right)$ was used and afterwards, for pest control (Spodoptera frugiperda, Rhopalosip hummaidis and Diabrotica speciosa) present in the millet crop, Methomyl $215 \mathrm{~g} \mathrm{~L}^{-1}$ (1.0 L c.p. ha ${ }^{-1}$ ), Acephate $750 \mathrm{~g} \mathrm{~kg}^{-1}$ (1.0 kg c.p. ha- ${ }^{-1}$ ) and Teflubenzurom $150 \mathrm{~g} \mathrm{~L}^{-1}(200$ $\mathrm{mL}$ c.p. $\mathrm{ha}^{-1}$ ) were used, making the area suitable for sowing.
Demarcation of the sowing lines as well as fertilization were carried out by using a tractor using a seeder-fertilizer. In order to prevent larva pinchin (Diabrotica speciosa) and soil disease (Fusarium oxysporum), seeds were treated with Pyraclostrobin $25 \mathrm{~g} \mathrm{~L}^{-1}$, Thiophanate Methyl $225 \mathrm{~g} \mathrm{~L}^{-1}$ and Fipronil $250 \mathrm{~g} \mathrm{~L}^{-1}$ (200 mL c.p./100 kg of seeds). Then, sowing was manually performed at a depth of $0.05 \mathrm{~m}$ with a population of 300,000 plants ha-1.

Based on crop demand and soil chemical analysis (SOUZA; LOBATO, 2004), $200 \mathrm{~kg} \mathrm{ha}^{-1}$ of N-P $\mathrm{O}_{5}-\mathrm{K}_{2} \mathrm{O}$ (10$30-20)+30 \mathrm{~kg} \mathrm{ha}^{-1}$ of MAP were used on sowing fertilization, carried out on February 27 in both years. Two topdressing fertilizations were performed at 30 and 45 days after emergence (DAE), using 45 and $20 \mathrm{~kg} \mathrm{ha}^{-1}$ of nitrogen (urea), respectively.

In relation to the invasive plants, three applications were carried out at 15,30 and 45 DAE using the herbicides Fomesafem $250 \mathrm{~g} \mathrm{~L}^{-1}\left(1.0 \mathrm{~L} \mathrm{ha}^{-1}\right)$, Haloxyfop-P-Methyl $240 \mathrm{~g}$ $\mathrm{L}^{-1}\left(0.4 \mathrm{~L} \mathrm{ha}^{-1}\right)$

Pest (Bemisia tabaci, Diabrotica speciosa, Nezara viridula and Spodoptera frugiperda) control was performed by applying five insecticides: Thiamethoxam $250 \mathrm{~g} \mathrm{~kg}^{-1}(250 \mathrm{~mL}$ c.p.ha-1), Beta-Cyfluthrin $50 \mathrm{~g} \mathrm{~L}^{-1}\left(100 \mathrm{~mL}\right.$ c.p. ha $\left.{ }^{-1}\right)$, Acephate $750 \mathrm{~g} \mathrm{~kg}^{-1}$ (1 kg c.p. ha-1), Lambda-Cyhalothrin $50 \mathrm{~g} \mathrm{~L}^{-1}$ (250 $\mathrm{mL}$ c.p. ha ${ }^{-1}$ ) and Chlorpyrifos $480 \mathrm{~g} \mathrm{~L}^{-1}$ (1.5 L c.p. ha ${ }^{-1}$ )

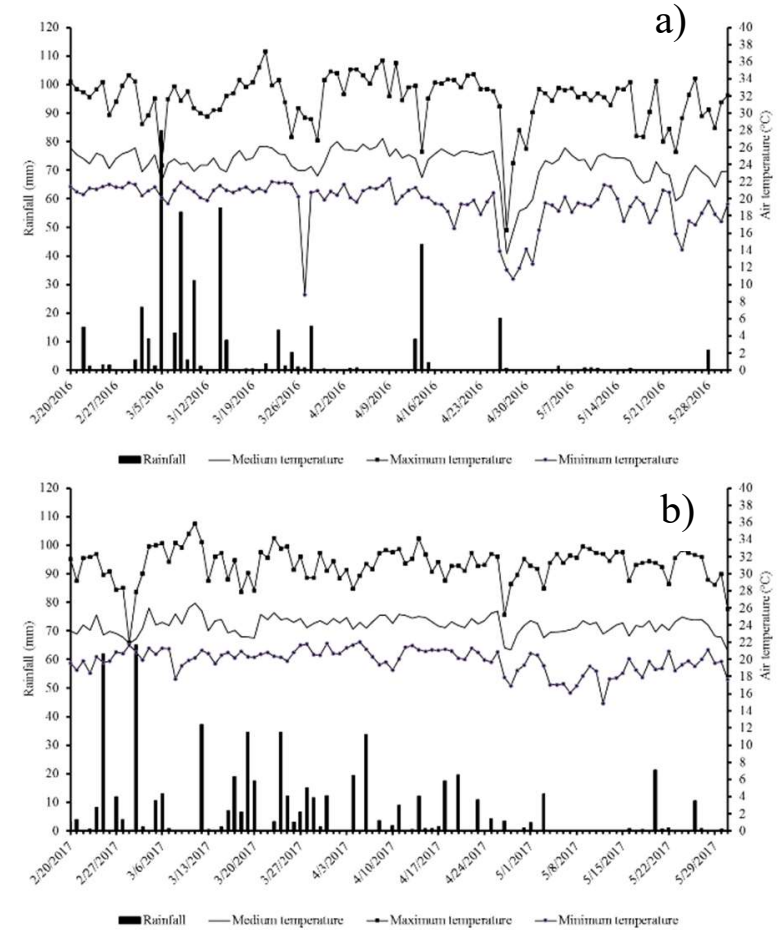

Figure 1. Rainfall and thermal averages verified in the experimental area from February to May 2016 (a) and 2017 (b) (Campo Novo do Parecis, MT, Brazil).

Figura 1. Precipitação pluviométrica e médias térmicas verificadas na área experimental no período de fevereiro a maio de 2016 (a) e 2017 (b) (Campo Novo do Parecis, MT, Brasil).

Disease (Phaeoisa riopsisgriseola and Uromyces appendiculatus) control was carried out using fungicide Difeconazol $250 \mathrm{~g} \mathrm{~L}^{-1}\left(300 \mathrm{~mL}\right.$ c.p. ha $\left.{ }^{-1}\right)$, with applications at 30,45 and 60 days after sowing (DAS).

The agronomic characteristics evaluated in 10 plants per plot were, as follows: plant height (PH; $\mathrm{cm})$, according to the development of each cultivar, measured from the base of the 
plant up to the end of the guide, using a measuring tape; stem diameter (SD; $\mathrm{mm})$, measured with digital caliper at $5 \mathrm{~cm}$ from ground level; days for initial flowering (DIF), from sowing until $50 \%$ of the plants were flowered; days for physiological maturation (DFM) from sowing to harvest; number of pods per plant (NPP), by field count at harvest; number of grains per pod (NGP), determined by counting grains and pods; and number of grains per plant (NGP), obtained by the product between NPP and NGP.

The mass of one hundred grains (MHG; g) determined in the laboratory was evaluated by counting and weighing $(0.01$ g) a sample of 100 grains in each sample plot and the grain yield (GY; $\mathrm{kg} \mathrm{ha}^{-1}$ ), determined by means of the two $4.0-\mathrm{m}$ center rows, discarding $0.5 \mathrm{~m}$ from the ends. Harvesting was performed manually, on May 26 and 27 in 2016 and 2017, respectively, when the plants reached $\mathrm{R} 9$ (physiological maturity), followed by natural drying and mechanical threshing (Vencedora B-350 model), with subsequent weighing and correction of moisture content of the grains $(13 \%$ w.b.). Data were submitted to analysis of variance and Scott-Knott mean test, both at 5\% probability (FERREIRA, 2011).

\section{RESULTS}

Table 1 presents data on the analysis of variance for the agronomic characteristics of the second harvest black beans (averages of 2016 and 2017) in Campo Novo do Parecis - MT, where it is verified that only plant height $(\mathrm{PH})$ and number of pods per plant (NPP) were statistically significant by the F test $(\mathrm{p}<0.05)$.

The coefficients of variation $(\mathrm{CV})$ for plant height $(\mathrm{PH})$, stem diameter (SD, days for initial flowering (DIF), days for physiological maturation (DFM), number of pods per plant
(NPP), number of grains per pod (NGP), number of grains per plant (NGP), mass of one hundred grains (MHG) and grain yield (GY) ranged between low (up to 10\%), medium (between 10 and 20\% ) and high (between 20 and 30\%), according to the magnitude defined by Pimentel-Gomes; Garcia (2002), according to Table 1. However, to know whether a particular $\mathrm{CV}$ is too high or too low requires experience with similar data, since $\mathrm{CV}$ is very useful for specifying the accuracy of experimental results with some efficiency, since it allows comparisons between variables of different nature and gives an idea on data accuracy.

Table 1. Summary of the analysis of variance for the agronomic characteristics of black common beans in the second harvest (averages of 2016 and 2017), Campo Novo do Parecis, MT.

Tabela 1. Resumo da análise de variância para as características agronômicas de feijão preto em segunda safra (médias de 2016 e 2017), Campo Novo do Parecis, MT.

\begin{tabular}{cccc}
\hline Variables $^{1}$ & $\mathrm{~F}^{2}$ & $\mathrm{CV}(\%)^{3}$ & $\mathrm{OM}^{4}$ \\
\hline PH $(\mathrm{cm})$ & $3.1^{*}$ & 10.5 & 59.6 \\
SD (mm) & $1.0^{\text {ns }}$ & 7.8 & 4.9 \\
DIF & $1.1^{\text {ns }}$ & 6.0 & 44.0 \\
DPM & $1.2^{\text {ns }}$ & 8.4 & 82.0 \\
NPP & $2.4^{*}$ & 20.4 & 7.0 \\
NGP & $1.2^{\text {ns }}$ & 11.2 & 3.9 \\
NGPL & $2.0^{\text {ns }}$ & 17.3 & 26.9 \\
MHG $(\mathrm{g})$ & $1.0^{\text {ns }}$ & 5.5 & 19.5 \\
GY $\left(\mathrm{kg} \mathrm{ha}^{-1}\right)$ & $1.1^{\text {ns }}$ & 21.8 & 654.6
\end{tabular}

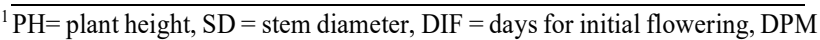
$=$ days for physiological maturation, $\mathrm{NPP}=$ number of pods per plant, NGP $=$ number of grains per pod, NGPL = number of grains per plant, $\mathrm{MHG}=$ mass of one hundred grains, GY = grain yield; ${ }^{2 \mathrm{~ns}}, * *$ and $*$ are not significant and significant at 1 and $5 \%$, respectively; ${ }^{3} \mathrm{CV}=$ Coefficient of variation; ${ }^{4} \mathrm{OM}=$ Overall mean.

Table 2. Average values for plant height (PH), stem diameter (SD), days for initial flowering (DIF), days for physiological maturation (DFM), number of pods per plant (NPP), number of grains per pod (NGP), number of grains per plant (NGPL), one hundred grain mass (MHG) and grain yield (GY) of black common bean genotypes grown in the second crop (averages of 2016 and 2017), Campo Novo do Campo Parecis, MT.

Tabela 2. Valores médios para a altura de planta (APL), diâmetro do caule (DCA), dias para o florescimento inicial (DFI), dias para a maturação fisiológica (DMF), número de vagens por planta (NVP), número de grãos por vagem (NGV), número de grãos por planta (NGP), massa de cem grãos (MCG) e produtividade de grãos (PRG) de genótipos de feijão preto cultivado em segunda safra (médias de 2016 e 2017), Campo Novo do Parecis, MT.

\begin{tabular}{cccccccccc}
\hline Genotypes & $\begin{array}{c}\text { PH } \\
(\mathrm{cm})\end{array}$ & $\begin{array}{c}\text { SD } \\
(\mathrm{mm})\end{array}$ & $\begin{array}{c}\text { DIF } \\
(\text { days })\end{array}$ & $\begin{array}{c}\text { DPM } \\
(\text { days })\end{array}$ & NPP & NGP & $\begin{array}{c}\text { NGPL } \\
\begin{array}{c}\text { MOG } \\
(\mathrm{g})\end{array}\end{array} \begin{array}{c}\text { GY } \\
\left(\mathrm{kg} \mathrm{ha}^{-1}\right)\end{array}$ \\
\hline CNFP 15670 & $51.4 \mathrm{~b}$ & $4.6 \mathrm{a}$ & $45.0 \mathrm{a}$ & $83.0 \mathrm{a}$ & $5.7 \mathrm{~b}$ & $4.0 \mathrm{a}$ & $22.9 \mathrm{a}$ & $19.1 \mathrm{a}$ & $621.1 \mathrm{a}$ \\
IPR TUIUIU** & $51.6 \mathrm{~b}$ & $4.9 \mathrm{a}$ & $42.0 \mathrm{a}$ & $80.0 \mathrm{a}$ & $5.4 \mathrm{~b}$ & $4.2 \mathrm{a}$ & $22.5 \mathrm{a}$ & $19.4 \mathrm{a}$ & $652.5 \mathrm{a}$ \\
CNFP 15676 & $51.7 \mathrm{~b}$ & $5.2 \mathrm{a}$ & $44.0 \mathrm{a}$ & $82.0 \mathrm{a}$ & $7.3 \mathrm{a}$ & $3.7 \mathrm{a}$ & $27.3 \mathrm{a}$ & $19.6 \mathrm{a}$ & $554.0 \mathrm{a}$ \\
CNFP 15685 & $55.1 \mathrm{~b}$ & $5.0 \mathrm{a}$ & $46.0 \mathrm{a}$ & $83.0 \mathrm{a}$ & $6.3 \mathrm{~b}$ & $4.4 \mathrm{a}$ & $26.8 \mathrm{a}$ & $20.0 \mathrm{a}$ & $573.9 \mathrm{a}$ \\
IPR UIRAPURU* & $57.5 \mathrm{~b}$ & $4.6 \mathrm{a}$ & $43.0 \mathrm{a}$ & $82.0 \mathrm{a}$ & $7.1 \mathrm{~b}$ & $4.0 \mathrm{a}$ & $28.3 \mathrm{a}$ & $19.1 \mathrm{a}$ & $666.8 \mathrm{a}$ \\
CNFP 15695 & $58.1 \mathrm{~b}$ & $5.2 \mathrm{a}$ & $42.0 \mathrm{a}$ & $81.0 \mathrm{a}$ & $9.8 \mathrm{a}$ & $3.4 \mathrm{a}$ & $32.4 \mathrm{a}$ & $19.7 \mathrm{a}$ & $642.9 \mathrm{a}$ \\
CNFP 15681 & $61.4 \mathrm{a}$ & $4.8 \mathrm{a}$ & $45.0 \mathrm{a}$ & $84.0 \mathrm{a}$ & $5.9 \mathrm{~b}$ & $3.8 \mathrm{a}$ & $22.9 \mathrm{a}$ & $19.2 \mathrm{a}$ & $644.6 \mathrm{a}$ \\
BRS FP403 & $62.1 \mathrm{a}$ & $4.7 \mathrm{a}$ & $43.0 \mathrm{a}$ & $81.0 \mathrm{a}$ & $8.4 \mathrm{a}$ & $3.8 \mathrm{a}$ & $32.5 \mathrm{a}$ & $20.4 \mathrm{a}$ & $716.6 \mathrm{a}$ \\
CNFP 15697 & $63.4 \mathrm{a}$ & $4.7 \mathrm{a}$ & $44.0 \mathrm{a}$ & $82.0 \mathrm{a}$ & $7.7 \mathrm{a}$ & $3.7 \mathrm{a}$ & $29.3 \mathrm{a}$ & $20.1 \mathrm{a}$ & $752.8 \mathrm{a}$ \\
CNFP 15678 & $66.4 \mathrm{a}$ & $4.9 \mathrm{a}$ & $45.0 \mathrm{a}$ & $82.0 \mathrm{a}$ & $6.0 \mathrm{~b}$ & $4.0 \mathrm{a}$ & $24.5 \mathrm{a}$ & $19.1 \mathrm{a}$ & $628.0 \mathrm{a}$ \\
CNFP 15684 & $67.2 \mathrm{a}$ & $5.0 \mathrm{a}$ & $46.0 \mathrm{a}$ & $84.0 \mathrm{a}$ & $7.6 \mathrm{a}$ & $4.0 \mathrm{a}$ & $30.7 \mathrm{a}$ & $18.8 \mathrm{a}$ & $769.4 \mathrm{a}$ \\
BRS ESTEIO* & $69.1 \mathrm{a}$ & $4.6 \mathrm{a}$ & $42.0 \mathrm{a}$ & $80.0 \mathrm{a}$ & $6.4 \mathrm{~b}$ & $3.6 \mathrm{a}$ & $22.5 \mathrm{a}$ & $19.1 \mathrm{a}$ & $633.0 \mathrm{a}$ \\
\hline
\end{tabular}

* = Standard genotype; Distinct letters are different from each other by the test of Scott-Knott at 5\% probability.

Plant height is important for the management to be carried out, for example, in the number of plants per meter, when there is the occurrence of problems in sowing, planting more seeds than the recommended, which may result in lodging of the plants. Thus, genotypes BRS Estacio, CNFP 15684, CNFP 15678, CNFP 15697, BRS FP403 and CNFP 15681 achieved the highest $\mathrm{PH}$ (Table 2), while the smallest $\mathrm{PH}$ were verified for CNFP 15670, IPR TUIUIU, CNFP 15676, CNFP 15685 , IPR Urartu and CNFP 15695.

Regarding SD, no significant difference was found between the evaluated genotypes (Tables 1 and 2). The genotypes flowered (DIF) between 42 (IPR TUIUIÚ, CNFP 15695 and BRS ESTEIO) and 46 days (CNFP 15685 and CNFP 15684), but did not present any statistical difference 
between them ( $p>0.05)$, according to Tables 1 and 2 neither for physiological maturity (DPM), whose cycles of genotypes were between 80 (IPR TUIUIÚ and BRS ESTEIO), which were the earliest, and 84 days (CNFP 15681 and CNFP 15684).

In relation to NPP, genotypes CNFP 15676, CNFP 15695, BRS FP403, CNFP 15697 and CNFP 15684 displayed the highest values, differing from the others, not presenting statistical difference among each other (Table 2).

No significant difference was found for NGP among the evaluated genotypes (Tables 1 and 2) neither for NGPL; however, BRS FP403 presented the highest value, while IPR TUIUIÚ and BRS Estacio, displayed the lowest values.

No statistical difference was found for one hundred grain mass among the evaluated genotypes (Tables 1 and 2), however, it should be noted that the numerical variation observed was between 18.8 (CNFP 15684) and $20.4 \mathrm{~g}$ (BRS FP403). There was also no statistical difference between genotypes for GY, whose minimum and maximum values were observed for CNFP 15676 and CNFP 15684, respectively.

\section{DISCUSSION}

In relation to $\mathrm{PH}$, the values of the present study are close to those obtained by Damari et al. (2015), who achieved PH of $56.6 \mathrm{~cm}$ for the IPR Urartu genotype when evaluating the agronomic traits of beans in non-preferential season whereas in a study by Salgado et al. (2011), when evaluating the behavior of bean genotypes during the between-harvest in Guruji (TO) observed that the IPR Uirapuru showed PH of $75.3 \mathrm{~cm}$, a result larger than that found in this study (Table 2).

Higher height of plants are important in mechanized harvesting because as long as the plants are erect, it facilitates their cutting by the platform, reducing losses and enhancing the quality of the product since the platform does not work in contact with the ground, reducing the amount of impurities at threshing.

The SD is of great importance for plant architecture since thick and rigid stems may avoid its lodging (VALE et al., 2012), not interfering in the harvest, which results in better quality grains. For this agronomic characteristic, IPR Uirapuru presented a greater value (Table 2) than that of Vale et al. (2012), who obtained a value of $3.7 \mathrm{~mm}$ when evaluating the mentioned genotype, at the moment that SD did not present statistical significance, either.

The NPP achieved for the IPR Uirapuru was below that reported by Vale et al. (2012), who obtained values of 8.1 in water stress condition and 13.6 at normal (no stress) condition. The results of IPR Uirapuru (Table 2) allow us to conclude that the genotype does not have a water stress tolerance capacity because in unfavorable conditions, it did not achieve good results, with the occurrence of abortion of flowers and pods, resulting in low NPP, due to low water availability during the reproductive phase (flowering and pod filling), especially in 2016 (Figures 1a,b). According to Guimarães et al. (2006), besides presenting a low capacity to recover from droughts, beans are very sensitive to water deficit. These findings are in line with those of Garrido (1998), who reported that when water deficit occurs during flowering, it results in low NPP and NGP, which had been observed in the present study.
Vale et al. (Table 2) found a value of 4.3 grains per pod for IPR Uirapuru genotype, which was slightly greater than that achieved in this study (Table 2), both of which were lower than the value obtained by Salgado et al. (2011), 12.4 grains per pod when evaluating the behavior of bean genotypes in the between-harvest with the use of irrigation, therefore, such value was expected since there was no water limitation to the crop.

In relation to NGPL, Vale et al. (2012) reported 34.8 grains per plant for IPR Uirapuru, close to that found in this study (Table 2). For IPR Uirapuru, the value for MHG (Table 2) was lower than that of Salgado et al. (2011), who achieved a value of $29.3 \mathrm{~g}$ for the genotype in question, which was also lower than that of Silva et al. (2016), $27.6 \mathrm{~g}$, when evaluating bean genotypes in a Red Eutrophic Latosol in Campinas - SP. Indeed, the low values verified in this study are attributable to the occurrence of water stress in the reproductive phase of the crop (R5 and R8) as well as the high temperatures, since beans are very sensitive to water stress and extreme temperatures (Figures 1a,b).

It is known that bean grain yield is generally directly related to its production components (NPP, NGP, NGPL and MHG). Hence, when the performance of such components is not satisfactory, it is common the occurrence of low productivities such as those shown in Table 2, since they are interdependent factors.

Water deficit was the factor that most limited GY of the crop in a study carried out in the North of Minas Gerais (GARRIDO, 1998). At the beginning and at the end of flowering, or at the beginning of pod formation and growth, they caused reductions of 16, 42 and 58\% in PRG.

In addition, according to Back (2001), studies show that water deficits for periods of 14, 17 and 20 days during emergence and flowering reduce grain yields by 20, 38 and $52 \%$, respectively. As a result, it was observed that the edaphoclimatic conditions in which beans are grown reflect directly on their reproductive performance so that drought is the factor that contributes the most to its failure (GUIMARÃES et al., 2006; RAMALHO et al., 2009), resulting in low grain yield as observed in this study (Table 2), especially in 2016 (Figures 1a,b), when April was practically dry, except on day 14, when a rainfall of $44 \mathrm{~mm}$ occurred after 15 days without rain during the reproductive period, resulting in the low productive performance in the year as well as in the composition of the averages of the two years. Similarly, May was very dry, in both years, at the final moment of the grain filling, with direct reflection on the productive performance of the beans.

\section{CONCLUSIONS}

Black bean is a crop that grows well on Parecis plateau because it presents the optimum plant height for mechanized harvesting and stem diameter that provides good resistance to lodging.

Its grain yield can be satisfactory as long as there is no water stress especially at the beginning of flowering and at the grain filling stage.

Among the assessed genotypes, BRS FP403, CNFP 15697 and CNFP 15684 presented the best grain yields (greater than $700 \mathrm{~kg} \mathrm{ha}^{-1}$ )

To achieve a good income, investment is necessary because this crop is demanding especially in water. 


\section{ACKNOWLEDGEMENTS}

To Grupo de Pesquisa em Fitotecnia (GPF) at Instituto Federal de Educação Ciência e Tecnologia de Mato Grosso Campus Campo Novo do Parecis for supporting and helping the achievement of this study and to Empresa Brasileira de Pesquisa Agropecuária (Embrapa Arroz e Feijão - CNPAF), for supporting the experiment.

\section{REFERENCES}

BACK, A. J. Necessidade de irrigação da cultura de feijão no sul do estado de Santa Catarina. Revista de Tecnologia e Ambiente, Criciúma, v. 7, n. 1, p. 35-44, 2001.

DALCHIAVON, F. C.; MONTANARI, R.; ANDREOTTI, M.; DALLACORT, R.; SOUZA, M. F. P. Relationship between sunflower productivity and soil's chemical properties by geo-statistical techniques. African Journal of Agricultural Research, Nairobi, v. 10, n. 35, p. 35253532 , 2015.

DOI: https://dx.doi.org/10.5897/AJAR2014.9472

DALLACORT, R.; MARTINS, J. A.; INOUE, M. H.; FREITAS, P. S. L.; COLETTI, A. J. Distribuição das chuvas no município de Tangará da Serra, médio norte do Estado de Mato Grosso, Brasil. Acta Scientiarum Agronomy, Maringá, v. 33, n. 2, p. 193-200, 2011. DOI: http://dx.doi.org/10.4025/actasciagron.v33i2.5838

DEMARI, G. H.; SOUZA de V. Q.; CARVALHO, I. R.; NARDINO, M.; FOLLMANN, D. N. Feijão em época não preferencial submetido a doses de nitrogênio e seu impacto nos caracteres agronômicos. Enciclopédia Biosfera, Jandaia, v. 11, n. 21, p. 1102-1112, 2015.

EMPRAPA EMPRESA BRASILEIRA DE PESQUISA AGROPECUÁRIA. Sistema brasileiro de classificação de solos. Brasília: Embrapa Produção de informação, 2013. $353 \mathrm{p}$.

FAO_Food and Agriculture Organization. Statistic/FAOSTAT. 2010. Disponível em: $<$ http://www.fao.org/statistics/pt/>. Acesso em: $02 \mathrm{Jul}$. 2017.

FERREIRA, D. F. Sisvar: a computer statistical analysis system. Ciência e Agrotecnologia, Lavras, v. 35, n. 6, p. 1039-1042, 2011. DOI: http://dx.doi.org/10.1590/S141370542011000600001

GARRIDO, M. A. T. Respostas do feijoeiro às lâminas de água e adubação nitrogenada. 1998. 205f. Tese (Doutorado em Agronomia/Fitotecnia). Universidade Federal de Lavras, Lavras, 1998.

GUIMARÃES, C. M.; STONE, L. F.; BRUNINI, O. Adaptação do feijoeiro comum (Phaseolus vulgaris L.) à seca. Revista Brasileira de Engenharia Agrícola e Ambiental, Campina Grande, v. 10, n. 1, p. 70-75, 2006. DOI: 43662006000100011

MELO, L. C.; MELO, P. G. S.; FARIA, L. C.; DIAZ, J. L. C.; DEL PElOSO, M. J.; RAVA, C. A.; COSTA, J. G. C. Interação com ambientes e estabilidade de genótipos de feijoeiro-comum na Região Centro-Sul do Brasil.
Pesquisa Agropecuária Brasileira, Brasília, v. 42, n. 5, p. 715-723, 2007. DOI: http://dx.doi.org/10.1590/S0100204X2007000500015

PEREIRA, H. S.; MELO, L. C.; FARIA, L. C.; DEL PELOSO, M. J.; COSTA, J. G. C.; RAVA, C. A.; WENDLAND. A Adaptabilidade e estabilidade de genótipos de feijoeiro-comum com grãos tipo carioca na Região Central do Brasil. Pesquisa Agropecuária Brasileira, Brasília, v. 44, n. 1, p. 29-37, 2009. DOI: http://dx.doi.org/10.1590/S0100-204X2009000100005

PIMENTEL-GOMES, F. P.; GARCIA, C. H. Estatística aplicada a experimentos agronômicos e florestais. Piracicaba: FEALQ, 2002. 309p.

RAMALHO, M. A. P.; SILVA, G. S.; DIAS, L. A. S. Genetic plant improvement and climate changes. Crop Breeding and Applied Biotechnology, Viçosa, v. 9, n. 2, p. 189195, 2009. DOI: http://dx.doi.org/10.12702/19847033.v09n02a11

SALGADO, F. H. M.; FIDELIS, R. R.; CARVALHO de G. L.; SANTOS, dos G. R.; CANCELLIER, E. L.; SILVA, G. F. Comportamento de genótipos de feijão, no período da entressafra, no sul do estado de Tocantins. Bioscience Journal, Uberlândia, v. 27, n. 1, p. 52-58, 2011.

SANTOS, C. M. dos; CARVALHO, M. A. C. de; RODRIGUES, M.; NOUJAIN FILHO, N.; MENDES, E. D. R. Comportamento de genótipos de feijão na época "das águas" no Norte de Mato Grosso. Revista de Ciências Agro-Ambientais, Alta Floresta, v. 11, n. 1, p.17-26, 2013.

SILVA da D. A.; ESTEVES, J. A de F.; GONÇALVES, J. G. R.; AZEVEDO, C. V. G.; RIBEIRO, T.; CHIORATO, A. F.; CARBONELL, S. A. M. Avaliação de genótipos de feijoeiro quanto à eficiência do uso do fósforo em Latossolo Vermelho Eutrófico. Bragantia, Campinas, v. 75 , n. 2, p. 152-163, 2016. DOI: http://dx.doi.org/10.1590/1678-4499.454

SOUSA, D. M. G. de; LOBATO, E. Cerrado: correção do solo e adubação. 2. ed. Brasília: Embrapa Cerrados, 2004. 416 p.

SOUZA, R. F. de; FAQUIN, V.; FERNANDES, L. A.; AVILA, F. W. de. Nutrição fosfatada e rendimento do feijoeiro sob influência da Calagem e adubação orgânica. Ciência e Agrotecnologia, Lavras, v. 30, n. 4, p. 656-664, 2006. DOI: http://dx.doi.org/10.1590/S141370542006000400010

TSUTSUMI, C. Y.; BULEGON, L. G.; PIANO, J. T. Melhoramento genético do feijoeiro: avanços, perspectivas e novos estudos, no âmbito nacional. Nativa, Sinop, v. 03, n. 03, p. 217-223, 2015. DOI: http://dx.doi.org/10.14583/2318-7670.v03n03a12

VALE, do M. N.; BARILI, D. L.; ROZZETO, S. D.; STINGHIN, C. J.; COIMBRA, M. L. J.; GUIDOLIN, F. A.; KÖOP, M. M. Avaliação para tolerância ao estresse hídrico em feijão. Revista Biotemas, Florianópolis, v. 25, n. 3, p. 135-144, 2012. http://dx.doi.org/ 10.5007/21757925.2012v25n3p135 